\title{
Environmental factors and symptoms in infants at high risk of allergy
}

\author{
MICHAEL L BURR, ${ }^{1}$ FRANCIS G MISKELLY, ${ }^{2}$ BARBARAK BUTLAND, ${ }^{1}$ TERENCE \\ G MERRETT, ${ }^{3}$ AND ELAINE VAUGHAN-WILLIAMS ${ }^{1}$ \\ From ${ }^{1}$ the MRC Epidemiology Unit, 4 Richmond Road, Cardiff; ${ }^{2}$ Prince Charles Hospital, Merthyr Tydfil, Mid \\ Glamorgan; and ${ }^{3}$ RAST Allergy and Research Unit, Benenden Hospital Trust, Benenden, Cranbrook, Kent
}

\begin{abstract}
Study objective: To identify environmental determinants of six symptoms associated with allergic disease in infancy.

Design: Infants were participants in a prospective randomised controlled trial of feeding practices in families with a history of atopy.

Setting: Infants were recruited in two maternity hospitals in $\mathrm{S}$ Wales and followed up in the community for 1 year.

Participants: Mothers of 519 infants agreed to participate, but 36 were excluded (mainly for moving home or failing to attend for follow-up), leaving 483 in the study ( 253 male, 230 female). Infants were followed up and examined for evidence of allergic disease at 3,6 and 12 months.

Measurements and main results: At each examination, mothers were questioned about episodes of illness in the infant, and the data presented relate to (reported and observed) eczema and nasal discharge, and (reported) wheeze, prolonged colds, diarrhoea and vomiting. Mothers kept a diary with details of feeding for the first 6 months. All homes were visited by a nurse who took samples of dust for dust mite antigen analysis. Extensive socio-demographic data were collected. None of the factors studied showed a convincing relationship with eczema. In a multiple logistic regression analysis breast feeding appeared to protect against wheeze, nasal discharge, colds, vomiting and diarrhoea. Having more siblings increased the likelihood of prolonged colds, and (together with overcrowding) of wheeze and nasal discharge. Maternal smoking and low social class were associated with wheeze, and house dust antigen with prolonged colds. Respiratory symptoms were associated with some aspects of housing but these could not be distinguished clearly from other social factors. Babies born in Autumn were at increased risk of wheeze, vomiting and diarrhoea.

Conclusions: Environmental factors play an important part in determining risk of symptoms in potentially atopic babies. These factors are in principle open to manipulation.
\end{abstract}

Social and environmental factors appear to have an important relationship with disease in infancy. The infant mortality rate in 1981 for legitimate births in England and Wales showed a continuous gradient from 7.7 per thousand live births in social class I to 15.8 per thousand in social class V. ${ }^{1}$ Presumably this gradient represents a potential for improving the health of infants in lower social classes if only the adverse factors could be identified and corrected.

Allergic disease has a strong genetic component: children born to atopic parents have a higher incidence of asthma and wheezing than other children. Environmental factors also seem to be involved, since the concordance rate for allergy in monozygotic twins is less than $100 \%$. This paper presents data obtained during the first year of life from a cohort of infants in atopic families, showing how various environmental factors were related to the development of symptoms.

\section{Methods}

The infants in this study were born in two maternity hospitals in South Wales. They were selected antenatally as having a parent or sibling with a history of eczema, asthma or hay fever.

They participated in a randomised controlled trial of withholding cow's milk, soya milk being substituted for those who were not breast fed. Details of the trial 
have been published separately. ${ }^{2}$ The infants were seen by a doctor (FGM) at 3,6 and 12 months of age, and examined for evidence of disease. The mothers were questioned at the same time about episodes of illness which had occurred since the baby was last seen. For the first 6 months a diary was kept by the mother in which details of the baby's diet were recorded. Each house was visited by a nurse who took samples of dust from the child's mattress, the mother's mattress, and the carpet on which the child was most frequently placed. These specimens were analysed for content of house dust mite antigen (Dermatophagoides pteronyssinus) by means of an inhibitory radioimmunoassay, utilising ${ }^{125}$ I-Der $\mathrm{pl}$ and a double antibody separation step.

\section{Results}

There were 519 live born infants (including six pairs of twins) whose mothers agreed to participate. Of these, eight were born (or were about to move) outside the area, five were omitted because their birthweight was less than $2 \mathrm{~kg}$, nine mothers failed to cooperate from the start, one baby died aged 3 weeks, and 13 failed to attend for follow up at 12 months. The data presented here relate to 483 infants ( 253 male, 230 female) and six symptoms: eczema and nasal discharge, as observed by the physician; and wheeze, prolonged colds, diarrhoea and vomiting, as reported by the mother. Wheeze was defined as a whistling sound, whether high or low pitched, coming from the child's chest; prolonged colds were colds which lasted 2 weeks or more. Information was incomplete in some cases, so the incidence rates relate to denominators slightly below the total numbers of infants. The numbers for which information was available about each symptom are shown in the tables. Wheeze occurred in $40 \%$ $(100 / 252)$ of the boys and in $29 \%(66 / 230)$ of the girls $(p<0.05)$; the other symptoms showed little or no sex difference.
The incidence of symptoms in different social classes is shown in table 1 . The infants were classified by the father's occupation; the mother's occupation was coded if she was a single parent, or if her husband was unemployed and she was employed. The "unemployed" (UE) group included a few students. Ten infants are omitted from this table, since information about their social class was not available. Eczema and prolonged colds showed no association with social class. Wheeze and vomiting had a continuously rising incidence as social class declined, though the trend for vomiting was not statistically significant. Here and in tables $2-4$ the Wilcoxon rank sum test was used for significance testing.

Table 2 examines the incidence of the six symptoms according to the presence of cigarette smokers in the house at any time during the first year of life; two infants are omitted as the information was not available. The effect of smoking was particularly marked for wheeze, maternal smoking being associated with a substantial rise in incidence, while smokers other than the mother had an intermediate effect. A similar though less striking trend was seen with prolonged colds. Nasal discharge was higher if the mother smoked than if she did not, but the presence of other smokers in the house made no difference.

In Table 3 the infants are classified according to the number of siblings. A rise in incidence with increasing number of siblings occurred for wheeze, nasal discharge and prolonged colds. No significant trends existed for the other symptoms, although the incidence of diarrhoea was particularly high $(82 \%)$ in the largest families.

For each infant an "overcrowding index" was obtained by dividing the number of persons in the house by the number of rooms. Overcrowding was significantly associated with both wheeze and nasal discharge, the mean index being 0.83 and 0.73 respectively in infants with and without wheeze, and

Table 1 Incidence by social class ( $n=$ number of infants about whom information was available)

\begin{tabular}{|c|c|c|c|c|c|c|c|}
\hline \multirow[b]{2}{*}{ Social class } & \multirow[b]{2}{*}{$\begin{array}{l}\text { Number of } \\
\text { infants }\end{array}$} & \multicolumn{6}{|c|}{ Incidence of symptoms (\%) } \\
\hline & & $\begin{array}{l}\text { Eczema } \\
(n=459)\end{array}$ & $\begin{array}{l}\text { Wheeze } \\
(n=472)\end{array}$ & $\begin{array}{l}\text { Nasal discharge } \\
(n=458)\end{array}$ & $\begin{array}{l}\text { Prolonged colds } \\
(n=472)\end{array}$ & $\begin{array}{l}\text { Vomiting } \\
(n=472)\end{array}$ & $\begin{array}{l}\text { Diarrhoea } \\
(n=(472)\end{array}$ \\
\hline $\mathbf{I}+\mathbf{I I}$ & 63 & 33 & 21 & 41 & 38 & 44 & 59 \\
\hline IIINM & 56 & 42 & 23 & 33 & 21 & 50 & 64 \\
\hline IIIM & 167 & 42 & 31 & 41 & 40 & 55 & 73 \\
\hline IV & 46 & 35 & 33 & 46 & 54 & 57 & 63 \\
\hline $\mathbf{v}$ & 56 & 34 & 45 & 42 & 36 & 59 & 73 \\
\hline UE & 85 & 36 & 51 & 59 & 46 & 67 & 76 \\
\hline $\begin{array}{l}\text { Test for trend } \\
\text { (excluding UE) }\end{array}$ & & NS & $\mathrm{p}<0.01$ & NS & NS & NS & NS \\
\hline
\end{tabular}

$\mathrm{UE}=$ unemployed 
Table 2 Incidence by smoking category ( $n=$ number of infants about whom information was available)

\begin{tabular}{|c|c|c|c|c|c|c|c|}
\hline \multirow[b]{2}{*}{ Smoking category } & \multirow[b]{2}{*}{$\begin{array}{l}\text { Number of } \\
\text { infants }\end{array}$} & \multicolumn{6}{|c|}{ Incidence of symptoms (\%) } \\
\hline & & $\begin{array}{l}\text { Eczema } \\
(n=468)\end{array}$ & $\begin{array}{l}\text { Wheeze } \\
(n=480)\end{array}$ & $\begin{array}{l}\text { Nasal discharge } \\
(n=467)\end{array}$ & $\begin{array}{l}\text { Prolonged colds } \\
(n=480)\end{array}$ & $\begin{array}{l}\text { Vomiting } \\
(n=480)\end{array}$ & $\begin{array}{l}\text { Diarrhoed } \\
(n=480)\end{array}$ \\
\hline No cigarette smokers & 229 & 39 & 26 & 42 & 35 & 52 & 67 \\
\hline $\begin{array}{l}\text { Smoker in house, } \\
\text { not mother }\end{array}$ & 85 & 36 & 33 & 41 & 40 & 60 & 72 \\
\hline Mother smokes & 167 & 38 & 47 & 48 & 46 & 59 & 72 \\
\hline Test for trend & & NS & $p<0.001$ & NS & $p<0.05$ & NS & NS \\
\hline
\end{tabular}

Table 3 Incidence by number of siblings ( $n=$ number of infants about whom information was available)

\begin{tabular}{|c|c|c|c|c|c|c|c|}
\hline \multirow[b]{2}{*}{$\begin{array}{l}\text { Number of } \\
\text { siblings }\end{array}$} & \multirow[b]{2}{*}{$\begin{array}{l}\text { Number of } \\
\text { infants }\end{array}$} & \multicolumn{6}{|c|}{ Incidence of symptoms (\%) } \\
\hline & & $\begin{array}{l}\text { Eczema } \\
(n=469)\end{array}$ & $\begin{array}{l}\text { Wheeze } \\
(n=482)\end{array}$ & $\begin{array}{l}\text { Nasal discharge } \\
(n=468)\end{array}$ & $\begin{array}{l}\text { Prolonged colds } \\
(n=482)\end{array}$ & $\begin{array}{l}\text { Vomiting } \\
(n=482)\end{array}$ & $\begin{array}{l}\text { Diarrhoea } \\
(n=482)\end{array}$ \\
\hline $\mathbf{0}$ & 197 & 35 & 22 & 30 & 30 & 51 & 66 \\
\hline 1 & 170 & 41 & 37 & 53 & 43 & 59 & 72 \\
\hline 2 & 78 & 34 & 44 & 51 & 51 & 62 & 68 \\
\hline $3-6$ & 38 & 47 & 66 & 59 & 53 & 61 & 82 \\
\hline All & 483 & 38 & 34 & 44 & 40 & 56 & 70 \\
\hline Test for trend & & NS & $p<0.001$ & $p<0.001$ & $p<0.001$ & NS & NS \\
\hline
\end{tabular}

0.79 and 0.73 in those with and without nasal discharge $(p<0.001$ for wheeze, $p<0.01$ for nasal discharge, using the Wilcoxon rank sum test). No significant associations were found with eczema, prolonged colds, vomiting or diarrhoea.

Samples of dust were obtained from the homes of 392 babies. Levels of mite antigen were strongly related to the age of the mattresses and carpets from which they were taken. Table 4 shows the relationship between four symptoms and the highest mite antigen score found in the three samples for each baby. The incidence of prolonged colds rose significantly with rising mite antigen levels; a similar trend for nasal discharge just fell short of statistical significance.

The relationship between the incidence of symptoms and month of birth was examined. No obvious pattern existed for eczema, nasal discharge or prolonged colds. The incidence of wheeze and vomiting was higher in infants born in each of the 4 months August-November than for any other month, while the incidence of diarrhoea was higher in infants born in each of the 6 months July-December than for any other month.

Table 5 shows that babies who were breast fed for any length of time had about half the incidence of wheeze compared with those who were never breast fed, the difference being highly significant. Babies who were breast fed at any time were less likely to have prolonged colds than those never breast fed; similar tendencies were found for vomiting and diarrhoea, while for nasal discharge the difference fell just short of statistical significance. No relationship was found

Table 4 Incidence by maximum mite antigen exposure. ( $n=$ number of infants about whom information was available)

\begin{tabular}{|c|c|c|c|c|c|}
\hline \multirow[b]{2}{*}{$\begin{array}{l}\text { Mite antigen } \\
\text { concentration }(\mu)\end{array}$} & \multirow[b]{2}{*}{$\begin{array}{l}\text { Number of } \\
\text { infants }\end{array}$} & \multicolumn{4}{|c|}{ Incidence of symptoms (\%) } \\
\hline & & $\begin{array}{l}\text { Eczema } \\
(n=389)\end{array}$ & $\begin{array}{l}\text { Wheeze } \\
(n=391)\end{array}$ & $\begin{array}{l}\text { Nasal discharge } \\
(n=389)\end{array}$ & $\begin{array}{l}\text { Prolonged colds } \\
(n=391)\end{array}$ \\
\hline $1-100$ & 149 & 37 & 30 & 38 & 32 \\
\hline $101-1119$ & 113 & 35 & 38 & 46 & 38 \\
\hline $1120-19914$ & 130 & 38 & 35 & 50 & 47 \\
\hline Test for trend & & NS & NS & NS & $p<0.05$ \\
\hline
\end{tabular}

* maximum value for each child in sample taken from that house 
128 Michael L Burr, Francis G Miskelly, Barbara K Butland, Terence G Merrett, and Elaine Vaughan-Williams

Table 5 Incidence by breast feeding ( $n=$ number of infants about whom information was available)

\begin{tabular}{|c|c|c|c|c|c|c|c|}
\hline & \multirow[b]{2}{*}{$\begin{array}{l}\text { Number of } \\
\text { infants }\end{array}$} & \multicolumn{6}{|c|}{ Incidence of symptoms (\%) } \\
\hline & & $\begin{array}{l}\text { Eczema } \\
(n=469)\end{array}$ & $\begin{array}{l}\text { Wheeze } \\
(n=482)\end{array}$ & $\begin{array}{l}\text { Nasal discharge } \\
(n=468)\end{array}$ & $\begin{array}{l}\text { Prolonged colds } \\
(n=482)\end{array}$ & $\begin{array}{l}\text { Vomiting } \\
(n=482)\end{array}$ & $\begin{array}{l}\text { Diarrhoea } \\
(n=482)\end{array}$ \\
\hline $\begin{array}{l}\text { Breast fed at some } \\
\text { time }\end{array}$ & 190 & 35 & 22 & 39 & 33 & 46 & 59 \\
\hline Never breast fed & 293 & 40 & 43 & 47 & 44 & 63 & 76 \\
\hline Significance level & & NS & $\mathrm{p}<0.001$ & NS & $p<0.05$ & $\mathrm{p}<0.001$ & $p<0.001$ \\
\hline
\end{tabular}

between breast feeding and eczema. In these and the following comparisons $\chi^{2}$ tests were used, with Yates' correction for continuity.

Three aspects of housing were considered further: open coal fires, damp patches and mould growth on the walls, as reported by the mothers. The incidence of wheezing was significantly $(\mathrm{p}<0.05)$ higher in houses with open coal fires $(33 / 71,46 \%)$ than in other houses $(132 / 409,32 \%)$; similar tendencies were found with regard to the presence and absence of dampness $(40 \%$ and $31 \%$ respectively) and mould $(41 \%$ and $32 \%$ respectively), although these differences just fell short of statistical significance. Nasal discharge did not show any relationship with these housing factors, but prolonged colds occurred more often in the presence $(80 / 173,46 \%)$ than in the absence $(107 / 303,35 \%)$ of damp $(p<0.05)$. The presence or absence of cats, dogs, other mammalian pets and birds in the house was unrelated to the incidence of symptoms.

\section{MULTIPLE LOGISTIC REGRESSION ANALYSIS}

Many of the variables under consideration were related to each other. A multiple logistic regression analysis was employed to examine the extent to which different factors had independent effects. Table 6 shows the order in which certain variables entered the model as the result of a forward selection procedure. Breast feeding was treated as a continuous variable (number of weeks) when this improved the fit of the model more than the simple dichotomous variable (ever versus never); in consequence, the continuous variable was used for nasal discharge, colds and diarrhoea, and the single factor for wheeze and vomiting. Birth months were grouped: AugustNovember versus December-July for wheeze and vomiting, and July-December versus January-June for diarrhoea. For each symptom the residual deviance is relatively large, and reference to a $\chi^{2}$ distribution suggests significant lack of fit in each case.

Table 6 Analysis of deviance for multiple logistic regression models

\begin{tabular}{|c|c|c|c|c|c|}
\hline Dependent variable & Step & Variable entered & $d f$ & Deviance & Change in deviance $(d f=1)$ \\
\hline Wheeze & $\begin{array}{l}0 \\
1 \\
2 \\
3 \\
4 \\
5\end{array}$ & $\begin{array}{l}\text { Constant } \\
\text { Siblings } \\
\text { Birth month } \\
\text { Breast fed } \\
\text { Sex } \\
\text { Damp }\end{array}$ & $\begin{array}{l}459 \\
458 \\
457 \\
456 \\
455 \\
454\end{array}$ & $\begin{array}{l}590.6 \\
564.9 \\
545.0 \\
531.6 \\
525.7 \\
520 \cdot 7\end{array}$ & $\begin{array}{r}- \\
25 \cdot 7 \pm \\
19 \cdot 9 t \\
13 \cdot 4 t \\
5.9 * \\
5 \cdot 0^{*}\end{array}$ \\
\hline Nasal discharge & $\begin{array}{l}0 \\
1 \\
2\end{array}$ & $\begin{array}{l}\text { Constant } \\
\text { Breast fed } \\
\text { Siblings }\end{array}$ & $\begin{array}{l}385 \\
384 \\
383\end{array}$ & $\begin{array}{l}530 \cdot 1 \\
522 \cdot 3 \\
514 \cdot 3\end{array}$ & $\begin{array}{l}- \\
7.8 t \\
7.9 t\end{array}$ \\
\hline Colds & $\begin{array}{l}0 \\
1 \\
2\end{array}$ & $\begin{array}{l}\text { Constant } \\
\text { Siblings } \\
\text { Breast fed }\end{array}$ & $\begin{array}{l}385 \\
384 \\
383\end{array}$ & $\begin{array}{l}513.9 \\
506 \cdot 1 \\
498.9\end{array}$ & $\begin{array}{l}- \\
7 \cdot 8 t \\
7 \cdot 2 t\end{array}$ \\
\hline Vomiting & $\begin{array}{l}0 \\
1 \\
2\end{array}$ & $\begin{array}{l}\text { Constant } \\
\text { Breast fed } \\
\text { Birth month }\end{array}$ & $\begin{array}{l}465 \\
464 \\
463\end{array}$ & $\begin{array}{l}640 \cdot 6 \\
626 \cdot 3 \\
619 \cdot 7\end{array}$ & $\begin{array}{r}-14 \cdot 4 t \\
6 \cdot 6 *\end{array}$ \\
\hline Diarrhoea & $\begin{array}{l}0 \\
1 \\
2\end{array}$ & $\begin{array}{l}\text { Constant } \\
\text { Breast fed } \\
\text { Birth month }\end{array}$ & $\begin{array}{l}469 \\
468 \\
467\end{array}$ & $\begin{array}{l}577 \cdot 6 \\
559 \cdot 7 \\
553 \cdot 0\end{array}$ & $\begin{array}{r}- \\
17.9 t \\
6.7 \dagger\end{array}$ \\
\hline
\end{tabular}

$* 00.05 ; \quad+p<0.01 \quad \mp p<0.001$ 
The goodness of fit statistics tested for lack of agreement between the final model and observed values of the binary variable representing presence or absence of symptoms.

The odds ratios for the risk associated with each variable within the multiple logistic regression analysis are shown in table 7. Smoking and social class were added to the model for wheeze produced by forward selection, because the forward selection procedure was not very sensitive in detecting trends. The odds ratio for smokers other than the mother was 1.00 in comparison with no smoker in the house, so smoking was treated as a dichotomous variable, according to whether the mother did or did not smoke. The incidence of wheeze was significantly and independently related to number of siblings, month of birth, breast feeding (negatively), male sex and maternal smoking. When social class was added to the model, the effect of dampness just ceased to be statistically significant; again, the incidence of wheeze rose steadily as social class declined. For both nasal discharge and prolonged colds independent significant effects existed for number of siblings (positive) and duration of breast feeding (negative). For vomiting and diarrhoea the factors which emerged as significant in the multiple logistic regression analysis were breast feeding (negatively), and month of birth.

\section{Discussion}

The symptoms under consideration are likely to be the product of a variety of genetic, allergic, infective and irritant factors. The results suggest that environmental factors play a substantial part in determining the incidence of symptoms in this high risk group. Since this study involved only children from atopic families it cannot be assumed that the results apply to other children. In so far as a genetic predisposition to atopy is necessary for the development of allergic symptoms, it seems likely that the environmental factors which promote or prevent allergy will exert their greatest effects among children with an atopic family history. In children without such a history the symptoms we have studied are presumably less likely to have an allergic basis and may well show different relationships with environmental agents. It is also possible that some environmental agents may have a greater effect in children without than in those with a family history, as suggested by Magnusson ${ }^{3}$ in regard of maternal smoking.

Furthermore, it must be recognised that a family has a shared environment as well as a shared heredity. If, for example, some environmental factor promotes eczema, our selection of infants with a family history of eczema is likely to have given us a population unusually exposed to this particular agent. It follows that even the babies who did not acquire eczema are more likely to have been exposed to this agent than are the generality of babies, so that the difference in exposure between babies who did and did not acquire eczema will have been reduced. This effect may have masked a true relationship between an environmental factor and an allergic symptom, but it is not likely to have generated a spurious one.

Table 7 Effects of certain variables on risk of symptoms in the multiple logistic regression analysis

\begin{tabular}{|c|c|c|c|}
\hline Dependent variable & Explanatory variable & Odds ratio & $95 \%$ confidence interval \\
\hline \multirow[t]{2}{*}{ Wheeze } & $\begin{array}{l}\text { Siblings, per sib } \\
\text { Born Aug-Nov : Dec-Jul } \\
\text { Breast fed ever : never } \\
\text { Sex F : M } \\
\text { Damp present : absent } \\
\text { Mother smoker : non-smoker } \\
\text { Social class v I + II: }\end{array}$ & $\begin{array}{l}1.48 t \\
2.61 \ddagger \\
0.53 t \\
0.61 \\
1.51 \\
1.61\end{array}$ & $\begin{array}{l}1.21-1.81 \\
1.66-4.13 \\
0.33-0.86 \\
0.40-0.94 \\
0.95-2.38 \\
1.03-2.52\end{array}$ \\
\hline & $\begin{array}{ll}\text { IIINM } \\
\text { IIIM } \\
\text { IV } \\
\text { V } \\
\text { UE }\end{array}$ & $\begin{array}{l}1.40 \\
1.47 \\
1.60 \\
2.33 \\
2.34^{*}\end{array}$ & $\begin{array}{l}0.55-3.54 \\
0.69-3.11 \\
0.63-4.10 \\
0.94-5.74 \\
1.04-5.28\end{array}$ \\
\hline Nasal discharge & $\begin{array}{l}\text { Breast fed, per week } \\
\text { Siblings, per sib }\end{array}$ & $\begin{array}{l}0.96 t \\
1.33 t\end{array}$ & $\begin{array}{l}0.93-0.99 \\
1.09-1.62\end{array}$ \\
\hline Colds & $\begin{array}{l}\text { Breast fed, per week } \\
\text { Siblings, per sib }\end{array}$ & $\begin{array}{l}0.96^{*} \\
1.33 t\end{array}$ & $\begin{array}{l}0.93-0.99 \\
1.09-1.63\end{array}$ \\
\hline Vomiting & $\begin{array}{l}\text { Breast fed ever : never } \\
\text { Born Aug-Nov : Dec-Jul }\end{array}$ & $\begin{array}{l}0.52 \pm \\
1.69 *\end{array}$ & $\begin{array}{l}0.35-0.76 \\
1.13-2.52\end{array}$ \\
\hline Diarrhoea & $\begin{array}{l}\text { Breast fed, per week } \\
\text { Born Jul-Dec : Jan-Jun }\end{array}$ & $\begin{array}{l}0.954 \\
1.70 t\end{array}$ & $\begin{array}{l}0.93-0.98 \\
1.14-2.55\end{array}$ \\
\hline
\end{tabular}

UE = unemployed

- $\mathrm{p}<0.05 ; \quad+\mathrm{p}<0.01 ; \quad \mp \mathrm{p}<0.001$ 
We do not know to what extent under reporting of symptoms occurred. The associations with prolonged colds (reported by the mothers) were similar to those with nasal discharge (observed by the doctor), which suggests that they were not attributable to selective reporting. Wheeze, vomiting and diarrhoea tended to be reported more commonly in the lower than in the upper social classes, contrary to any reporting bias which might be expected.

\section{WHEEZE}

There have been several reports of an association between parental smoking and respiratory symptoms in infancy and early childhood. ${ }^{4-8}$ In this study, maternal smoking was a major determinant of wheeze in the baby, but smoking by other persons in the household had no effect when other factors were allowed for. These findings concur with the results of at least two other prospective studies which showed paternal smoking to be relatively unimportant in this connection in comparison with maternal smoking. ${ }^{57}$ The cohort will be followed up to see whether the effect of maternal smoking persists into later childhood, as has been found by some investigators ${ }^{9-14}$ but not by others. $^{51516}$

The effect of social class on wheeze was strong and consistent, the continuous gradient being particularly striking. Obviously it represents the summation of many diverse factors and one can only speculate as to what causes the high incidence in the low social classes. Housing conditions may perhaps play some part: a recent survey in Edinburgh found that respiratory symptoms in childhood were associated with dampness and mould in the house. ${ }^{16}$ A survey of adults in South Wales found wheezing to occur more often in damp houses and in those with open coal fires. ${ }^{17}$ In the present study wheezing was associated with coal fires, dampness and mould, although the last two associations did not quite reach conventional levels of statistical significance in the univariate analysis. Number of siblings and overcrowding were clearly related to incidence of wheeze, presumably due to increased risk of infection.

There is a remarkable lack of agreement about the relationship between breast feeding and symptoms in potentially atopic infants. ${ }^{18}$ In the present study any breast feeding appeared to halve the risk of wheeze; this finding is discussed in more detail in a separate communication dealing with dietary factors, ${ }^{2}$ but it was not attributable to confounding with the other factors considered in table 7. Longer cohort studies have not shown breast feeding to be predictive against asthma at a later age. ${ }^{1920}$ Wheeze cannot of course be equated simply with asthma, particularly during early infancy when viral bronchiolitis and other respiratory infections are common, and breast feeding may protect against respiratory infection rather than respiratory allergy. It is noteworthy, however, that the incidence of wheezing in the boys was higher than that in the girls, and this may be related to the fact that asthma occurs more frequently in boys than in girls. ${ }^{21}$ It seems likely that the unknown mechanism which causes boys to have a greater bronchial reactivity than girls operates very early in life, being triggered by different factors at different ages.

The higher risk of wheezing among infants born during the months August to November may reflect the greater frequency of respiratory infections during the winter, when this group of babies would be at their most vulnerable. It is interesting to note that an effect of birth month may persist over many years. The data of Smith and Springett ${ }^{22}$ showed that children with asthma were more likely to have been born in each of the months May to November than would be expected. In the South West Thames Region, admission to hospital for asthma occurred more often among children born during October and November than among those born in any other month, in both the $1-4$ and the 5-14 year age groups. ${ }^{23}$ As the authors of that study concluded, it is likely that there is a real relationship between month of birth and the prevalence of respiratory disease, including asthma, but the mechanism remains obscure. In adults the relationship does not seem to be consistent; a Danish study ${ }^{24}$ found an excess of asthmatics born in each of the months May to November, but other workers have reported associations with births in December to February, ${ }^{25}$ March to June, ${ }^{26}$ or in two peaks March to May and September to November. ${ }^{27}$

\section{NASAL SYMPTOMS}

Nasal discharge and prolonged colds probably included viral, bacteriological and allergic elements, between which we did not attempt to distinguish. They were related positively to the number of siblings, no doubt because of an increased risk of infection in larger families, and negatively to duration of breast feeding, presumably by means of some immunological mechanism. This approach, using duration as a continuous variable among all infants, is more sensitive than our previous analysis ${ }^{2}$ which did not show a significant association between nasal discharge and duration of breast feeding among the breast fed infants alone. The house dust mite is a major allergen in atopic people, causing asthma and allergic rhinitis, so it is noteworthy that nasal symptoms were associated with exposure to mite allergen. Admittedly the associations were not statistically significant in the multiple logistic regression analysis, but in view of the interrelationships of the various factors studied it is difficult to distinguish between primary causes and confounding variables. 


\section{VOMITING AND DIARRHOEA}

The incidence of vomiting rose steadily as social class declined, although the trend was not statistically significant. A raised incidence of gastrointestinal disturbance among infants in lower social classes has been reported in other surveys. ${ }^{28} 29$ It is perhaps surprising that overcrowding and number of siblings did not affect the risk of vomiting and diarrhoea. In some studies parental smoking has been associated with gastrointestinal symptoms in infancy, ${ }^{728}$ but it did not appear to be a major factor in this study. Both vomiting and diarrhoea showed an inverse relationship with breast feeding. Since very few of these babies were exclusively breast fed it seems likely that breast feeding confers positive protection against these symptoms irrespective of other foods taken; similar conclusions were drawn from another recent cohort study. ${ }^{29}$ A case-control study in Brazil suggested that breast feeding reduced mortality from respiratory infection and diarrhoea by a combination of direct protection and shielding from contamination. ${ }^{30}$ The mechanism underlying the relationship with month of birth can only be conjectured, but presumably it arises from a combination of seasonal factors and changing risks at different ages, to the detriment of babies born in the autumn.

\section{IMPLICATIONS}

Some caution is needed in drawing causal inferences from an observational study. The environment factors which we studied were related to each other and no doubt to other factors which we did not study, some of which may have been more important. Obviously we did not attempt to investigate all the possible determinants of these symptoms, and the lack of fit of our final models presumably reflects the existence of various other relevant factors.

Despite these uncertainties, however, it seems reasonable to conclude that women who are atopic (or who have atopic husbands or children), and who wish to reduce the risk of symptoms in their children, would probably be well advised firstly to plan their pregnancies so that their babies do not arrive in the autumn; secondly, to breast feed their infants, even if not exclusively; and thirdly, not to smoke.

We are very grateful for financial grants received from the Welsh Scheme for the Development of Health and Social Research, and from Wyeth Laboratories.

Address for correspondence and reprints: Dr Michael L Burr, MRC Epidemiology Unit, 4 Richmond Road, Cardiff CF2 3AS, UK.
References

${ }^{1}$ Office of Population Censuses and Surveys. Mortality statistics, perinatal and infant: social and biological factors. Review of the Registrar-General on deaths in England and Wales 1981, Series DH3; no.13. London: HMSO 1985.

2 Miskelly FG, Burr ML, Vaughan-Williams E, Fehily AM, Butland BK, Merrett TG. Infant feeding and allergy. Arch Dis Child 1988; 63: 388-93.

${ }^{3}$ Magnusson CGM. Maternal smoking influences cord serum IgE and IgD levels and increases the risk for subsequent infant allergy. J Allergy Clin Immunol 1986; 78: 898-904.

${ }^{4}$ Harlap S, Davies AM. Infant admissions to hospital and maternal smoking. Lancet 1974; i: 529-32.

5 Fergusson DM, Horwood LJ, Shannon FT, Taylor B. Parental smoking and lower respiratory illness in the first three years of life. J Epidemiol Community Health 1981; 35: $180-4$.

${ }^{6}$ Chen Y, Li W, Yu S. Influence of passive smoking on admissions for respiratory illness in early childhood. $\mathrm{Br}$ Med J 1986; 293: 303-6.

${ }^{7}$ Ogston SA, Florey C du V, Walker CHM. Association of infant alimentary and respiratory illness with parental smoking and other environmental factors. $J$ Epidemiol Community Health 1987; 41: 21-5.

${ }^{8}$ Geller-Bernstein G, Kenett R, Weisglass L, Tsur S, Lahav M, Levin S. Atopic babies with wheezing bronchitis: follow-up study relating prognosis to sequential IgE values, type of early infant feeding, exposure to parental smoking, and incidence of lower respiratory tract infections. Allergy 1987; 42: 85-91.

${ }^{9}$ Norman-Taylor W, Dickinson VA. Dangers for children in smoking families. Community Med 1972; 128: 32-3.

10 Colley, JRT. Respiratory symptoms in children and parental smoking and phlegm production. $\mathrm{Br}$ Med J 1974; ii: $201-4$.

11 Bland JM, Bewley BR, Pollard V, Banks MH. Effects of children's and parents' smoking on respiratory symptoms. Arch Dis Child 1978; 53: 100-5.

12 Tager IB, Weiss ST, Munoz A, Rosner B, Speizer FE. Longitudinal study of the effects of maternal smoking on pulmonary function in children. $N$ Engl J Med 1983; 309: 699-703.

${ }^{13}$ Murray AB, Morrison BJ. The effect of cigarette smoke from the mother on bronchial responsiveness and severity of symptoms in children with asthma. J Allergy Clin Immunol 1986; 77: 575-81.

14 Cogswell JJ, Mitchell EB, Alexander J. Parental smoking, breast feeding, and respiratory infection in development of allergic diseases. Arch Dis Child 1987; 62: 338-44.

15 Schilling RSF, Letai AD, Hui SL, Beck GJ, Schoenberg JB, Bouhuys A. Lung function, respiratory disease and smoking in families. Am J Epidemiol 1977; 106: 274-83.

16 Martin CJ, Platt SD, Hunt SM. Housing conditions and ill health. Br Med J 1987; 294: 1125-7.

17 Burr ML, St. Leger AS, Yarnell JWG. Wheezing, dampness, and coal fires. Community Med 1981; 3: 205-9.

18 Burr ML. Does infant feeding affect the risk of allergy? Arch Dis Child 1983; 58: 561-5.

19 Taylor B, Wadsworth J, Golding J, Butler N. Breast feeding, eczema, asthma and hayfever. $J$ Epidemiol Community Health 1983; 37: 95-9.

20 Anderson HR, Bland JM, Patel S, Peckham C. The natural history of asthma in childhood. J Epidemiol Community Health 1986; 40: 121-9.

${ }^{21}$ Peckham C, Butler N. A national study of asthma in childhood. J Epidemiol Community Health 1978; 32: 79-85. 
132 Michael L Burr, Francis G Miskelly, Barbara K Butland, Terence G Merrett, and Elaine Vaughan-Williams

${ }^{22}$ Smith JM, Springett VH. Atopic disease and month of birth. Clin Allergy 1979; 9: 153-7.

${ }^{23}$ Anderson HR, Bailey PA, Bland JM. The effect of birth month on asthma, eczema, hayfever, respiratory symptoms, lung function, and hospital admissions for asthma. Int J Epidemiol 1981; 10: 45-51.

${ }^{24}$ Korsgaard J, Dahl R. Sensitivity to house dust mite and grass pollen in adults: influence of the month of birth. Clin Allergy 1983; 13: 529-35.

${ }^{25}$ Pearson DJ, Freed DLJ, Taylor G. Respiratory allergy and month of birth. Clin Allergy 1977; 7: 29-33.

${ }^{26}$ Carosso A, Ruffino C, Bugiani M. The effect of birth season on pollenosis. Ann Allergy 1986; 56: 300-6.
${ }^{27}$ Bjorksten F, Suoniemi I. Dependence of immediate hypersensitivity on the month of birth. Clin Allergy 1976; 6: 165-71.

${ }^{28}$ Said G, Patois E, Lellouch J. Infantile colic and parental smoking. Br Med J 1984; 289: 660.

${ }^{29}$ Eaton-Evans J, Dugdale AE. Effects of feeding and social factors on diarrhoea and vomiting in infants. Arch Dis Child 1987; 62: 445-8.

${ }^{30}$ Victora CG, Smith PG, Vaughan JP, Nobre LC, Lombardi C, Teixera AMB, Fuchs SMC, Moreira LB, Gigante LP, Barros FC. Evidence for protection by breast feeding against infant deaths from infectious diseases in Brazil. Lancet 1987; ii: 319-22.

Accepted for publication November 1988 